811.161.1:929 Маројевић. P.

811.161.1'362:811.163.41

811.16(497.11)

https://doi.org/10.18485/sj.2018.23.1.3

КСЕНИЈА Ј. КОНЧАРЕВИЋ

Универзитет у Београду

Филолошки факултет
Оригинални научни рад

Примљен: 04. 01. 2018.

Прихваћен: 29. 01. 2018.

\title{
ДОПРИНОС ПРОФЕСОРА РАДМИЛА МАРОЈЕВИЋА КОНФРОНТАЦИОНИМ И ТИПОЛОШКИМ ИСТРАЖИВАЮИМА РУСКОГ И СРПСКОГ ЈЕЗИКА
}

У раду се приказује и критички валоризује делатност професора Радмила Маројевића на утемељењу наше лингвистичке русистике, у првом реду конфронтационе анализе руског и српског језика, његови најважнији резултати и истраживачка проблематика која је била предмет његових преокупација, и сагледава се његов удео у историји наше и словенске лингвистичке мисли.

Кључне речи: лингвистичка русистика, конфронтациона и типолошка анализа руског и српског језика, историја српске славистике, Радмило Маројевић.

У научној методологији лингвистичке славистике значајно место припада и историјским истраживањима, којима је сврха изналажење законитости развоја научних парадигми и њихових теоријских основа, а тиме и боље разумевање и унапређивање њиховог садашњег стања. Са историјског аспекта проучава се социокултурна условљеност проучавања словенских језика на синхронијском и дијахронијском, монолингвалном и конфронтационом плану, затим мењање циљева и задатака, метода и поступака истраживања кроз историју, историјат појаве монографских и публикација у часописима и зборницима, прати се појава нових методолошких праваца (концептуалних система) и трендова. Посебно интересовање методологија истраживања сло-

*kkoncar@mts.rs 
венских језика показује за властити историјат, односно за лонгитудинално праћење теорије системско-структуралног, функционалног, конфронтационог и типолошког испитивања појава и елеманата словенских језика, за приказивање делатности најеминентнијих представника научне мисли на овом подручју, за реконструисање доминантних метода и приступа истраживањима у појединим епохама (исп.: Ђорђић 1957; Дамљановић 2000; Дамљановић, Кончаревић 2010; Кончаревић 2000; Кончаревић 2017; Маројевић 1986; Marojević 1987; Пипер 1997; Пипер 1998; Пипер 2010; Пипер 2017). Овај рад има за циљ да прикаже делатност корифеја наше лингвистичке русистике, у првом реду конфронтационе анализе руског и српског језика, професора Радмила Маројевића, његове најважније резултате и истраживачку проблематику која је била предмет његових преокупација, да сагледа његов удео у историји наше и словенске лингвистичке мисли.

Као теоријска подлога за концептуално заснивање конфронтационе анализе руског и српског језика проф. Радмилу Маројевићу послужио је диференцијални метод који је разрадио и у својим уџбеницима: Примери књижевног језика руског, Примери књижсевног језика пољског, Граматика рускогјезика и Граматика пољског језика доследно реализовао професор Радован Кошутић(1866-1949), а чија је најбитнија одлика инсистирање на систематском и поступном поређењу појава и елемената руског и српског као блискосродних језика који у процесу усвајања интерферентно делују један на други на фонетско-фонолошком, лексичко-семантичком, граматичком и лингвокултуролошком плану (детаљније исп. Кончаревић 2010). Радован Кошутић заузео је значајно место у историји наше русистике и као утемељивач руско-српске лексикографије, зачетник лингвокултурологије и наставе културе, бриљантни аналитичар и коментатор књижевних текстова - a све је то послужило професору Радмилу Маројевићу као основ за утемељење модерне конфронтационе анализе руског и српског језика у њеној фундаменталној и апликативној димензији. Отуда не треба да нас чуди чињеница да је први број Славистичког зборника у издању Савеза славистичких друштава Србије (1986) Радмило Маројевић као главни уредник посветио управо Радовану Кошутићу, истичући у Предговору (стр. 7) да „Кошутићу у спомен, новим научним хоризонтима у сусрет, Славистички зборник чини свој први корак”.

У овом зборнику професор Маројевић је објавио изузетно информативну студију, снабдевену богатом библиографском апаратуром, о лингвистичкој русистици у Југославији, њеном развоју, досадашњим резултатима и правцима истраживања, као и актуелним задацима који стоје пред њом (Маројевић 1986). Био је то пионирски преглед историјата, савременог стања и перспектива наше лингвистичке русистике у следећим сегментима: информатика и библиографска истраживања, лексикографија, утврђивање методолошких основа конфронтационе анализе, конфронтациона фонетика, конфронтациона анализа граматичког система, конфронтациона дериватологија, конфронтаци- 
она стилистика, лексикологија, фразеологија, утицаји руског језика на српски, преношење властитих имена на српски језик, наука о превођењу, лингвометодика, лингвокултурологија. Нема ниједне међу побројаним областима којима професор Маројевић није дао, ако не у моменту писања чланка а оно свакако у даљем вишедеценијском бављењу русистиком, пресудан допринос. Не сматрамо преувеличавањем тврдњу да је појава Радмила Маројевића у нашој русистици означила исти онакав преокрет као и својевремена појава Радована Кошутића. Нажалост, обојици су признања од колега стигла касно - што због овдашњег менталитета, што због огромног квалитативног и квантитативног одскакања њиховог опуса у односу на савременике. Време новог откривања Радмила Маројевића као русисте и слависте тек предстоји, и ово је скроман допринос томе прегнућу.

За разумевање научног опуса професора Маројевића битно је сагледати и време у коме он отпочиње своју делатност. Наиме, почевши од друге половине седамдесетих година, у српској русистици долази до знатних промена, које су посебно видљиве у радовима тадашњих лингвиста млађе генерације. Уочљиво се повећава број радова конфронтативне природе и све је шири круг питања која се у њима разматрају, а све су разноврснији и облици тих радова (докторске дисертације, магистарски радови и други монографски радови, научни чланци као и зборници чланака и реферата). Квантитативни пораст конфронтационих истраживања, који је готово неизбежно био праћен неједнаким методолошким квалитетом тих радова, изнедрио је током 80-их година и више добро утемељених руско-српских лингвистичких поређења (поред Р. Маројевића, истаћи ћемо допринос Ј. Матијашевић, Д. Мирић, П. Пипера, М. Радић-Дугоњић, М. Рељић, Б. Станковића, Б. Терзића, Б. Тошовића). Успон конфронтативних истраживања у српској русистици несумњиво је био подстакнут укупним развојем лингвистичке славистике и појединих њених грана, као и опште лингвистике и теорије конфронтационе анализе. Том периоду припада и објављивање прве граматике руског језика са конфронтационом усмереношћу: била је то Граматика руског језика Р. Маројевића (1984), за којом следи, са распоном од четири године, Руска граматика у поређењу са српскохрватском Бранка Тошовића (1988).

Готово да нема области лингвистичке русистике у којој професор Маројевић није оставио значајног трага. За проучавање староруског језика незаобилазне су монографије ${ }^{1}$, студије и расправе ${ }^{2}$ овог врсног дијахрони-

\footnotetext{
${ }^{1}$ Посесивне категорије у у руском језику (у своме историјском развитку и данас). Београд: Филолошки факултет, 1983; Посесивне изведенице у староруском језику: Антропонимски систем. Топонимија. „, Слово о полку Игореве”. Београд: Филолошки факултет, 1985.

${ }^{2}$ Наводимо само неке од научних чланака Р. Маројевића везаних за проучавање староруског језика: Историческое словообразование и хронология фонологических изменений. - Филологические науки, 5 (1985), стр. 38-42; Посесивне категорије у „, Слову о полку Игореве”. - Јуж-
} 
чара, који је историјским коментарима обогаћивао и монографске прегледе савремене руске граматике у поређењу са српском $(1984,2001)$, о којима ће касније бити више речи.

На методолошком плану најпре ћемо истаћи да је професор Маројевић разрадио типолошки метод напоредног проучавања руског и српског језика из дијахронијске и синхронијске перспективе ${ }^{3}$. Између осталог, проф. Маројевић у антологијском чланку из 1986. (в. нап. 3) утврдио је да руски и српски као словенски, блискосродни језици, имају много сличности, заснованих на њиховом прасловенском пореклу, али се битно типолошки и разликују (фонолошки, граматички, лексички, стилистички и лингвокултуролошки план), што је несумњив доказ, и, уједно, резултат њиховог индивидуалног историјског развоја. На фонолошком нивоу руски и српски језик из историјске перспективе, како уочава проф. Маројевић, имају заједничка типолошка обележја: 1. Губљење назалних вокала; 2. Губљење полугласника предњег и задњег реда; престало је и прасловенско разликовање вокала по квантитету /o/, /e/ као увек кратки, /a/, /и/, /y/ као увек дуги; 3.Упрошћен је вокалски систем, изгубљена фонема /ё/; изгубљено фонолошко разликовање између /и/ и /ы/. Типолошке разлике између руског и српског језика на фонолошком плану резултат су: 1. умекшавања полумеких сугласника (у руском језику је формирана опозиција меки - тврди сугласник као дистинктивно фонолошко обележје); 2. преображаја тонског у експираторни акценат, што је у руском језику довело до редукције вокала и до појаве неутрализације извесних фонолошких опозиција у неакцентованом положају. У српском језику нема парних тврдих и меких сугласника, задржао се тонски акценат, чува се вокално /p/, различито је вокализовање полугласника у јаком положају, остварен је прелазак /л/ у /o/, нема преласка /e/

нословенски филолог, 41 (1985), стр. 91-123; Прилози творбено-семантичкој реконструкиији староруских топонима. - Ономатолошки прилози, 6 (1985), стр. 1-58; Методолошка питаға творбено-семантичке реконструкиије средњовековних топонима (на примеру староруских назива градова) // Зборник Шесте југословенске ономастичке конференције / Уред. П. Ивић, Београд, Српска академија наука и уметности, 1987, стр. 135-139; О реконструкиији прасловенског система посесивних категорија и посесивних изведениия. - Јужнословенски филолог, 1987 , XLIII, стр. 17-40; O etimološkoj obradi staroruskih toponima. - Ономатолошки прилози, 1987, VIII, 1-24; О једном тумачеюу староруских назива градова. - Onomastica Jugoslavica, 12 (1987), стр. 227-239; Категория поссессивности как критерий подлинности «Слова о полку Игореве». - Филологические науки, 1990, 3, стр. 110-115; Семантичка двопланост посесивних изведеница типа Иванъковая у староруском језику: (уз тумачења граматике и семантике облика у руској историјској лингвистици). - Зборник Матице српске за филологију и лингвистику, 37 (1994), стр. 339-346; Этюды по грамматике древнерусского языка. I. (К прочтению Свинцовой грамоmыl). - Вопросы языкознания, 3 (1996), стр. 17-22; Методологические вопросы реконструкиии древнеславянских топонимов: деривационно-семантический и деривачионно-фонетический аспекты. - Вопросы языкознания, 3 (1997), стр. 76-88; Этюды по грамматике древнерусского языка. II. (Посессивы типа Творимиричь). - Вопросы языкознания, 2 (1998), стр. 51-59, и др.

${ }^{3}$ Типолошко диферениирање руског и српскохрватског језика (из дијахронијске и синхронијске перспективе). - Јужнословенски филолог, XLII, 1986, стр. 21-41. 
у /o/ као у руском језику, као ни фонолошке диференцијације парних тврдих - меких испред /o/. На морфолошком нивоу разлике настале у историјском процесу развоја присутне су у категорији рода, броја, падежа, категорије аниматности (биће / предмет), придевског вида, времена, као и у систему врста речи. У области лексике диференцирање се евидентира код глагола кретања, премештања или налажења предмета у простору, што је типично за руски, а потпуно изостаје у српском језику, и сл. Деривациони и синтаксички план, по мишљењу Р. Маројевића, није довољно испитан, а и лингвокултуролошком аспекту тек предстоји типолошко истраживање.

У синхронијској лингвистици истаћи ћемо, најпре, Маројевићево бављење утврђивањем методолошких основа конфронтационе анализе и терминологијом конфронтационих истраживања ${ }^{4}$. Разграничење конфронтационе и контрастивне анализе на основу тога да ли су предмет истраживања изразите разлике и супротности, или међујезичке сличности, професору Маројевићу није се чинило методолошки довољно аргументованим и ваљаним. Најпре, он уочава да је „методолошки неоправдано унапред полазити од тога да је нека појава у два језика истоветна или потпуно различита: даља и дубља истраживања показују често само да таква појава није била ваљано испитана". Осим тога, „сличности и контрасти у језицима који су предмет упоређивања у оквирима контрастивне анализе дијалектички су узајамно повезани, а та анализа треба да послужи оптималном усвајању установљених сличности и разлика у процесу учења језика" (стр. 28-29). Сугестија Р. Маројевића је да се на подручју примењене лингвистике и методике наставе страних језика користи термин контрастивна анализа, пошто се у настави превасходно указује на битне формалне и семантичке разлике између матерњег и страног језика, док у фундаменталној лингвистици предност треба дати термину конфронтащиона анализа, јер је њен предмет проучавања укупност истоветности, сличности и разлика између језика који се пореде. Конфронтационом лингвистиком проф. Маројевић назива, дакле, дисциплину која се бави паралелним испитивањем и упоређивањем двају (или неколико) језика на синхронијској равни. Циљ таквог испитивања јесте утврђивање истоветности, сличности и разлика у језичким структурама и на појединим њиховим нивоима, њихова класификација, систематизација и спознаја оптималних путева за превазилажење разлика између матерњег и страног језика (спречавање интерференције) и коришћење постојећих истоветности у циљу ефикаснијег практичног овладавања страним језиком. Поређење језичких система врши се на фонетско-фонолошком, граматичком (морфолошком и синтаксичком) ${ }^{5}$ и лексичко-семантичком нивоу,

${ }^{4}$ Конфронтациона (контрастивна) лингвистика и теорија превођења као научне дисциплине. - Зборник МС за филологију и лингвистику, 1987, ХХX, 2, стр. 27-32.

${ }^{5} \mathrm{O}$ конфронтационим истраживањима морфологије и синтаксе руског и српског језика в. нпр. Неопределенно-личные предложения в русском языке и их сербские эквиваленты: (о со- 
мада се она, како показују радови професора Маројевића, може проширити и на ниво текста и дискурса (макролингвистичка анализа), као и на подручје лингвокултурологије. Новина коју Маројевић уводи у конфронтационо проучавање руског и српског језика у његовој фундаменталној и апликативној димензији јесте повезивање са функционалним приступом језичком феномену, разрађеним у оквиру лингвистичког правца конституисаног управо крајем 70-их и током 80-их - функционалне граматике, односно граматике функционално-семантичких поља.

Радмило Маројевић је у низу радова дао фундаментални допринос конфронтационим истраживањима руског и српског језика на граматичком (исп. Пипер 1996, Пипер 2004) и лексичко-семантичком плану, о чему сведоче бројне студије у домаћим и страним часописима и зборницима (њихов библиографски преглед в. у: Пипер 1984; Пипер 1990; Кончаревић-Трнавац 2004; Вићентић-Пипер 2006, као и у персоналним библиографијама Радмила Маројевића). У доста својих радова професор Маројевић разрадио је и апликативни аспект примене резултата добијених фундаменталном анализом, пре свега на плану теорије и технике превођења ${ }^{6}$ (најбољи увид у методологију и резултате оваквих истраживања пружа књига Лингвистика и поетика превођења (међусловенски превод) из 1989. године.

отношении сопоставительной лингвистики и теории перевода) // Вопросы языкознания. № 2 (1993), стр. 96-106; К типологии русского и сербского языков // Советское славяноведение. № 4 (1995), стр. 63-76; Прилози методологији лингвистичких истраживања 1-2 // Контрастивна језичка истраживања: V. Нови Сад: Филозофски факултет, Друштво за примењену лингвистику Војводине, 1996, стр. 81-87; Интердепендација граматике и лексикологије у српском и руском језику // Научни састанак слависта у Вукове дане, 26, 2 (1997), стр. 91-99; Компаративно-историјски приступ класификацији врста речи у српском и руском језику // Научни састанак слависта у Вукове дане. 27, 2 (1998), стр. 39-48.

${ }^{6}$ Граматички проблеми превођења // Превођење и настава страних језика. - Београд: Удружење научних и стручних преводилаца Србије, Друштво за примењену лингвистику Србије, 1986, стр. 27-33; Поетика наслова и избор преводног еквивалента: (роман „Подросток” Ф.М. Достојевског) // Мостови, 17, 1 (65) (1986), стр. 42-49; Између Вука и Пушкина: Востоковљеви препеви српских народних песама // Мостови, 72 (1987), стр. 409-419; Лингвистика превођења кьижевног текста: „Живи и памти” Валентина Распутина у српскохрватском преводу // Мостови. 19, 3 (75) (1988), стр. 228-236; О превођењу друштвено-политичке лексике са српскохрватског језика на руски // Prevodilac. 8, 1 (1989), str. 31-39; Вишезначност поетског текста и проблеми његовог превођења: (,Двенадцать” А. Блока) // Јужнословенски филолог, 45 (1990), стр. 53-62; Руски речници: двојезични речници српскога језика // Задужбина, 3, 9 (1991), стр. 3; Први руски препеви Хасанагинице: (песничка полемика Востокова и Пушкина) // Анали Филолошког факултета. 19 (1992), стр. 257-264; Руски препеви лирике Десанке Максимовић: (метрика и ритмика, семантика и поетика) // Анали Филолошког факултета. 20 (2000), стр. 233-240; Између Вука и Пушкина - Востоковљеви препеви српских народних песама // Преводна књижевност, Београд: Удружење књижевних преводилаца Србије, 2001, стр. 324-334; Фразеолошки русизми у Горском вијениу. I: (израз „Милошем живиш” у 892. стиху) // Зборник Матице српске за књижевност и језик, 53, 1/3 (2005), стр. 337-347; Фразеолошки русизми у Горском вијениу. II : (израз „на главу погибоше” у 2688. стиху) // Зборник Матице српске за књижевност и језик. 53, 1/3 (2005), стр. 349-359. 
Најпотпуније је резултате својих истраживања професор Маројевић обликовао у књигама које представљају оригиналну научну синтезу - Граматика руског језика (1984) и Русская грамматика. Сопоставительная грамматика русского и сербского языков с историческими комментариями (2001).

Граматика руског језика Радмила Маројевића била је припремљена за штампу крајем 1983. године, а изашла је почетком 1984 у издању београдског Завода за уџбенике и наставна средства. У то време појавила се потреба за модернијом концепцијом граматичког приручника за стране језике. То је време када М. Папић пише Граматику франиуског језика, а 3. Жилетић и Ј. Ђукановић Граматику немачког језика. ${ }^{7}$ Граматика руског језика Р. Маројевића намењена је ученицима средњих школа и студентима. Аутор у Предговору истиче да је Граматика рађена као приручник за учење и наставу руског језика у српској говорној средини. Намењена је ученицима средњих школа, али и студентима виших школа и факултета. У Предговору се наводи да је граматички материјал класификован и дефинисан „prema morfološkosintaksičkim kategorijama, omogućava usvajanje gramatičkog sistema polazeći od oblika i sintaksičkih jedinica prema značenju”, док је излагање и упућивање конципирано тако да се граматички систем руског језика може усвајати „od pojmovno-semantičkih kategorija prema gramatičkim sredstvima za njihovo izražavanje". Поред тога што се материјал у овој граматици износи по морфосинтаксичком принципу, без стриктне поделе на морфологију и синтаксу, аутор ју је конципирао као функционалну, не следећи само традиционални формално-граматички приступ, већ се ослања и на осветљавање формалне граматике са функционално-семантичког аспекта, који полази од категоријалних значења долазећи до језичких средстава за њихово изражавање. Граматичке појаве објашњене су кроз њихову примену у оквиру реченице, у циљу илустровања њихове синтаксичке функције и значења. У наведеним примерима заступљен је основни лексички фонд, са мањим одступањима (нпр. лексема лишай не припада основном фонду, али пошто она у истом облику и значењу постоји и у српском језику, претпостављамо да је у овој граматици присутна због акценатског типа).

На макроплану, излагање граматичког материјала подељено је на поглавља, док параграф на микроплану представља најмању целину. Граматика садржи два већа поглавља: Фонолошки систем руског језика у поређењу са српским (с. 11-30), који обухвата параграфе 3-43; Граматички систем руског језика у поређењу са српским (с. 31-343) обухвата параграфе 44-563. Подела на одељке организована је на следећи начин: Предговор (стр. 3-4), Садржај (5-7), Именице (31-75), Придеви (75-91), Кратки придеви (91-104), Прилози

${ }^{7}$ Marko Papić, Gramatika francuskog jezika, Beograd, 1984; Jovan Đukanović, Zoran Žiletić, Gramatika nemačkog jezika, Beograd, 1983. 
(104-107), Предикативи (107-112), Степени поређења (112-124), Бројеви (124-144), Заменичке речи (144-167), Глаголи (167-217), Глаголски придеви (партиципи) (217-226), Глаголски прилози (226-230), а затим следи део који се односи на синтаксу: Чланови реченице (230-291), Проста реченииа (291-318), Сложена реченица (318-336). Граматика има 343 странице, а цео саджај је подељен на 563 параграфа. Метод селективног презентовања језичких чињеница примењен је у складу с њиховом фреквентношћу и значајем за учење језика. У Граматици је доследно примењен конфронтативни (контрастивни) приступ језичким чињеницама. Ситнијим слогом су дати најнужнији компаративно-историјски коментари, ради бољег разумевања природе разлика између руског и српског језика, мада су они више намењени наставницима и студентима него ученицима. У теоријском погледу аутор је, по сопственим речима, тежио да одрази савремено стање науке о руском језику (као извори наведени су, између осталих, Русская грамматика, т. I-II, Москва, АН СССР, 1980, и Русская грамматика, т. I-II, Чехословачке академије наука из 1979). ${ }^{8}$ Називи граматичких појмова наводе се на српском и руском језику. При објашњењу појединих облика апаратуром оријентације упућује се на одговарајући параграф у Граматици. Сви руски примери су акцентовани.

Поређење руског и српског језика у Маројевићевим граматикама одликује се низом специфичности, које су на нивоу методолошких и методичких стандарда у доба њихове појаве, који су и данас актуелни. У једном нашем раду насталом убрзо након појаве Граматике руског језика из 1984. уочили смо и детаљно образложили основна начела конфронтационог постављања руског и матерњег језика ученика у овоме делу: 1) упоредљивост (пореде се појаве и елементи на приближно једнаком ступњу научне истражености, примењују се идентични методи за изучавање елемената и појава у оба језика); 2) системност (не пореде се изоловане јединице, него шире парадигматске групације: језички нивои, лексичко-семантичке групе, функционално-семантичка поља, синонимски редови итд.); 3) принцип терминолошке адекватности (усаглашеност употребе термина за означавање појава и елемената у оба контрастирана језика $)^{9}$; 4) принцип обостраног (двосмерног) поређења (од страног ка матерњем, који је доминантан, али и од матерњег ка страном језику); 5) принцип вођења рачуна о функционалним стиловима (пореде са чињенице језика само у оквирима истог стила, нпр. научног, информативно-публицистичког, званично-пословног); 6) принцип доминантно синхронијске анализе (пореди се углавном савремено стање језика, а дијахронијске чињенице се узимају у

${ }^{8}$ Н. Ю. Шведова (ред.), Русская грамматика, 1-2, ИРЯ АН СССР, Москва, 1980; Barnetová, V., Běličová H. et al. Русская грамматика, 1-2, Academia, Praha, 1979.

${ }^{9}$ Граматика руског језика Радмила Маројевића користи модеран појмовно-терминолошки апарат, а у вези с тим уочићемо да је то први граматички преглед ове врсте у српској и хрватској говорној средини која користи термине попут фонема, нулта морфема, нулта деклинаиија. 
обзир када су ирелевантне за формирање лингвистичке компетенције $\left.{ }^{10}\right)$; 7) принцип једноставности и приступачности (контрастивни опис разумљив је и прилагођен спознајним могућностима ученика, односно студената); 8) принцип минимизације (пореде се само оне појаве које улазе у фонетски, лексички, граматички, ортографски и лингвокултуролошки минимум за конкретну етапу учења); 9) принцип узимања у обзир територијалних дијалеката матерњег језика, нарочито на фонетско-фонолошком плану (нпр. ученицима се при усвајању фонеме [ш'ш':] скреће пажња на постојање аналогне црте у црногорским говорима, појава десоноризације звучних сугласника на крају речи среће се и у кајкавском дијалекту хрватског језика, компаративни суфикс -ее присутан је у косовско-ресавском дијалекту: добре́ju, нове́ju, акценат многих руских речи подудара се са дијалекатском акцентуацијом у нашим говорима: помо́zнете, уда́рити, има́ла, обра́доваћу се, каква́ итд.) и 10) принцип узимања у обзир фацилитације и међујезичке интерференције као фактора олакшавања или отежавања усвајања страног језика (исп. Кончаревић 1989).

Поређењем са претходним граматичким приручницима других аутора са српског и хрватског језичког подручја, Ружица Радојчић утврдила је у својој докторској дисертацији да ова Граматика доноси неке новине, пре свега када је реч о: а) класификацији именица - аутор их издваја и према месту акцента (на основи или на наставку); б) класификацији зависносложених реченица - аутор се држао приницпа по коме се, према његовом мишљењу, на бољи начин повезују чланови реченице, узимајући у обзир оне реченичне чланове који се развијају у зависну реченицу (нпр. објекатске реченице, адвербијалне реченице и сл). Ова Граматика уводи адвербијал друштва, а у оквиру просте, обрађене су и посесивне реченице. Вредност Маројевићеве Граматике састоји се у њеној применљивости, у приступачно презентованом садржају, а посебно у томе што је реч о првој контрастивној функционалној граматици руског језика у српској говорној средини (подробну анализу овога дела в. у: Радојчић 2016: 265-290).

На самом почетку XXI века из штампе је изашла Маројевићева Русская грамиатика. Сопоставительная грамматика русского и сербского языков с историческими комментариями ${ }^{11}$. Русская грамматика намењена је првенс-

${ }^{10}$ Дијахронијска објашњења, која се увек наводе после констатовања стања у синхронијској равни, визуелно су одељена од главног текста и штампана ситнијим слогом, што омогућава прегледност и олакшава служење књигом. Историјски коментари намењени су наставницима и студентима. Има их око 60, и то у првом делу (Морфологија). У овим коментарима није прецизно заступљено временско фиксирање у вези са настајањем и губљењем неке језичке појаве, тако да ученици не могу увек уочити историјски узрочно-последични след у развоју и мењању различитих језичких појава.

${ }^{11}$ Мароевич, Р. Русская грамматика: Сопоставительная грамматика русского и сербского языков с историческими комментариями, т.1, 2. Международный университет бизнеса и управления - Сербский фонд славянской письменности и культуры, Москва-Белград, 2001. 
твено корисницима у високошколским установама - руским студентима који изучавају српски језик, као и студентима руског језика у српској говорној средини. Поред тога што ова Граматика садржи више историјских коментара од претходне, приметне су још неке новине: а) врши се подела акцената на главне и побочне, што је илустровано примерима; б) издвајају се кратки придеви као посебна врста речи, поред предикатива; в) степени поређења су дати за све врсте речи које их имају; г) нове су и специфичности у класификацији заменица - упитне и односне се не раздвајају, већ се посматрају као две варијабле, док су показне и определительные приказане као једна врста заменица са даљом поделом, по којој, нпр. заменице этот и тот имају показно, тот же има идентификационо значење итд; д) издвојено се разматра заменица ничто; ђ) посебно је издвојен део Граматике у коме се говори о творби речи, мада су елементи творбе речи присутни и у другим деловима књиге; е) са творбеног аспекта, аутор раздваја прилоге од предлога, при чему су предлози мотифисани прилозима, у том смислу спустя може да буде и прилог; ж) уводи се термин грамматическое подлежащее, да би и српским студентима било јасније; з) разлике у употреби основних бројева у руском и српском језику, ново је навођење примера са предлогом на (на десять процентов больше/меньше); и) када је реч о прошлом времену, наводи се и пример за имперфекатско значење (Радојчић 2016: 291-293). Русская грамматика... поново је штампана 2015. у Бањој Луци (изд. Паневропски универзитет „Апеирон”).

Својеврсна научна синтеза јесте и лексикографско дело урађено под руководством професора Маројевића Основни руско-српскохрватски речник (приручник за ученике, студенте и наставнике) (коаутори М. Можаева, М. Маројевић) ${ }^{12}$, које се појавило непосредно након Граматике руског језика (1985). У састав речника ушли су: увод на српском и на руском језику (5-6), упутство како се служити речником такође на српском и руском језику (7-11), списак скраћеница (13), глосар (15-271), списак најфреквентнијих скраћеница на руском језику и кратка граматика са прегледом руске фонетике и прегледом руске граматике (275-295). У уводу се даје информација коме је речник намењен, циљ, принцип и критеријум избора, као и тип лексике која је ушла у састав речника. Речник је намењен говорницима српскохрватског језика који почињу самостално или уз помоћ наставника да уче руски језик. Циљ речника је стицање способности разумевања написаног текста, говорне речи и развијање комуникативне компетенције код ученика. Дидактичка усмереност условила је избор лексикографских одредница и начин њихове обраде, што долази до изражаја у начину давања фонетских и граматичких података, док су као критеријум за избор речи узети фреквентност, актуелност појма,

\footnotetext{
${ }^{12}$ Основни руско-српскохрватски речник: (приручник за ученике, студенте и наставнике) / Р. Маројевић, М. Маројевић, В.О. Можајева. Москва: Руски језик, Београд: Просвета, 1985, 294 стр.
} 
њена способност да улази у спојеве са другим речима, и могућност творбе других речи.

У речник је укључена лексика савременог руског језика потребна за комуницирање у „званичним и свакодневним ситуацијама”, како аутори истичу, као и за читање текстова средње тежине у новинама, часописима и из белетристике, разумевање радио и телевизијских емисија. Значења речи илуструју се примерима употребе речи на нивоу синтагме или реченице, који указују на карактеристично лексичко окружење или типичну граматичку конструкцију. У примерима се, где је то могуће, указује на неподударност у лексичкој спојивости руских речи и њихових српских еквивалената. Семантизација се врши и цртежима који објашњавају речи конкретног значења, као и фотографијама у боји које дају представу о природи, споменицима културе и природи земље чији се језик учи.

У речнику је примењен конфронтациони метод, који се заснива на систему поређења лексичких елемената у циљу избегавања узајамне интерференције. Речник садржи 5000 одредница.

Појаве међујезичке хомонимије, паронимије, полисемије, којима се професор Маројевић бавио у низу радова, аутори третирају системом упоређивања лексичких јединица, као у следећим примерима:

a) Када руским речима које нису синоними одговара исти српски еквивалент:

председа́mел $\| b,-я$ м председник (уп президе́нт) - президе́нт, - $а$ м председник (републике или високе научне установе уп. председа́тель)

яблок ||$о,-а$ мн -и, яблок с јабука (плод уп. яблоня) - яблон||я, -и мн -и, яблонь ж јабука (воћка уп. яблоко)

б) Кад руским речима које имају исто значење, али различиту граматичку употребу или стилску вредност, одговара исти српски еквивалент:

име́||mь, -ю, -ешь, -ют несврш. кого, что 1. имати (често у инф. уп. быть 2 и нет 2) ть больиу́ю библиоте́ку имати велику библиотеку; не ть детей немати деце; хорошо́ $\sim$ ть много друзей лепо је имати много пријатеља, ну́жно т ть опыт треба имати искуства.

быть 2. у кого имати (у личном обл. уп. иметь 1. и нет 2. у меня есть эта кни́га ја имам ову књигу, у них были де́ти имали су децу, у них не́ было дете́й нису имали децу, y тебя бу́дет вре́мя поду́мать имаћеш времена да размислиш, у нас не бу́дет вре́мени на это нећемо имати времена за то, есть биле́ты ? има ли карата?

нет 2. у предикат. функц. кого, чего у кого немам (немаш) кога шта или чега (уп. быть 2. и иметь 1.) у меня нет этой кни́ги ја немам ту књигу; у него́ нет свобо́дного вре́мени он нема слободног времена; у них нет дете́й они немају деце. 
в) У случајевима кад се руска реч и њен еквивалент у српском језику не подударају у целом обиму свог значења:

гром, - $а$ м грмљавина, гром (уп. молния 2) греми́m грми; разда́лся загрмело је. мо́лни ||я, -и ж 1 муња; сверкну́ла $\sim я$ севнула је муња 2 гром (уп. гром) я уда́рила в де́рево гром је ударио у дрво.

губ||á, -bl, мн. гу́бы, губ, -а́м, ж усна (уп. рот); ве́рхняя, ни́жняя á горња, доња усна; кра́сить гу́бы карминисати усне, карминисати се; поцелова́ть в гу́бы пољубити у уста. poт, рта, лок. о рте́, во рти́ м уста (уп. губа́); положи́ть конфе́ту в ставити бомбону у уста; го́рькии́ вкус во рту́ горак укус у устима; дыша́ть ртом дисати на уста.

г) Лексикографску обраду паронима илистроваћемо следећим примерима:

еди́ный 1. јединствен (уп. еди́нственный) - еди́нственный једини (уп. еди́ный) nростóp)

просто́р пространство (уп. простра́нство) - простра́нство простор (уп.

д) Посебна пажња поклања се обради међујезичких хомонима (ознака $y n$. овде долази на крају одреднице):

пу́шк||a топ; стрелять из $\sim$ пуцати из топа (уп. ружьё)

ружь||ё пушка; стрелять из я пуцати из пушке (уп. пу́шка)

ягод $\| a,-b l$ ж јагодаст плод (јагода, малина, трешња, зрно грожђа и сл.; уп. фpýкты); cnéлые bl клубни́ки зреле јагоде; собира́ть в лесу́ bl брати у шуми јагоде, малине, боровнице и сл.; варе́нье из ягод слатко од јагодастог воћа (уп. земляни́ка и клубни́ка)

клубни́к||a, -и нема мн. ж (баштенске) јагоде (уп. земляни́ка); выра́щивать $>$ гајити јагоде; варе́нье из $\sim$ слатко од (баштенских) јагода (уп. ягода)

земляни́к $\mid a$, -и нема мн. ж шумске јагоде (уп. клубни́ка и ягода)

Узимајући у обзир елементе речничке стуктуре и реализацију захтева школске лексикографије, Маја Павловић-Шајтинац у својој докторској дисертацији закључила је да овај речник испуњава све услове који су се пред школски речник у време његовог настајања могли постављати. Наиме, с обзиром на дидактичку усмереност све компоненте речничког чланка су подређене овој улози: дата је фонетска каратериситика, граматичке каратеристике омогућавају потпуну репродукцију промена код променљивих речи, особита пажња се поклања диференцијацији и граматичких категорија код одредница два језика у контакту, на семантичком нивоу указује се на појаве синонимије, унутрашње и међујезичке хомонимије, антонимије, паремије и полисемије (анализу овог речника в. у: Павловић-Шајтинац 2016: 246-265). Сви ови елементи имају за циљ развијање комуникативне и лингвистичке компетенције корисника речника.

Професор Радмило Маројевић оставио је снажан траг у историји лингвистичке русистике као научник великог формата, широких интересовања и несвакидашње узорности у селекцији и обради грађе за своја истраживања. Својим капиталним, ауторитативним и незаобилазним делом доказао је да спада међу највеће словенске филологе данашњице. 


\section{ЛИТЕРАТУРА}

Вићентић, Пипер 2006: Вићентић, Биљана и Предраг Пипер: Библиографија српске лингвистичке русистике 1991-2000. - Нови Сад: Матица српска. 2006.

Дамљановић 2000: Дамљановић, Дара: Руски језик у Србији. Уцбенищи до 1941. године. Београд: Филозофски факултет, Београд, 2000.

Дамљановић, Кончаревић 2010: Дамљановић, Дара и Ксенија Кончаревић: Настава и методика наставе руског језику у Србији у XIX и XX веку: Прилози за историју. Београд: Чигоја, 2010.

Ђорђић 1957: Ђорђић, Петар: Преглед рада на словенској филологији у Југославији у послератном периоду (1945-1955) из области упоредне граматике словенских језика са прасловенским, старословеског језика са његовим рецензијама и источних и западних словенских језика. - Beogradski međunarodni slavistički sastanak, uredio dr Kiril Taranovski. - Beograd: Izdanje organizacionog odbora, 1957, str. 63-78.

Кончаревић 1989: Кончаревић, Ксенија: Лингвистичке и лингвометодичке основе концепције нових дидактичких граматика руског језика у нас // Живи језици. - Год. ХХXI, бр. 1-4 (1989), стр. 85-92.

Кончаревић 2000: Кончаревић, Ксенија: Сто педесет година руског језика у Србији // Славистика. - Књ. 4 (2000), стр. 315-319.

Кончаревић 2010: Кончаревић, Ксенија: Рецепција дела Радована Кошутића у послератној русистичкој лингводидактици код Срба : о шездесетогодишњици смрти // Славистика. - Књ. 14 (2010), стр. 323-335.

Кончаревић 2017: Кончаревић, Ксенија: Јубилеј наше прве катедре за проучавање стране филологије: сто четрдесет година београдске славистике // К. Кончаревић (уред.), Универзитетска славистика: традииие, савремено стање, перспективе. Међународни научни зборник поводом 140 година Катедре за славистику Београдског универзитета $=$ Университетская славистика: традиции, современное состояние, перспективы. Международный сборник научных статей, посвященный 140-летию Кафедры славистики Белградского университета, Београд: Филолошки факултет Београдског универзитета, 2017, 11-24.

Кончаревић, Трнавац 2004: Кончаревић, Ксенија и Радослава Трнавац: Библиографија југословенске лингвистичке русистике (1985-1991). - Нови Сад: Матица српска, 2004. 
Кончаревич 2008: Кончаревич, Ксения: Сопоставительные лингводидактические исследования в сербской русистике : итоги и перспективы // Изучение славянских языков, литератур и культур как инославянских и иностранных : сборник докладов : VII Международный симпозиум МАПРЯЛ (Белград, 3-5 июня 2008). - Белград : Славистическое общество Сербии 2008, стр. 196-202.

Кончаревич, Дамлянович 2010: Кончаревич, Ксения и Дара Дамлянович: Русский язык в Сербии : традиции и современность // Русский язык в школе. - Бр. 11 (2010), стр. 72-77.

Маројевић 1986: Маројевић, Радмило: Радован Кошутић и развој југословенске лингвистичке русистике. У књ.: Славистички зборник. Кьига I: Радован Кошутић и развој југословенске славистике. - Београд: Савез славистичких друштава СР Србије, 1986, 31-46.

Маројевић 1987: Маројевић, Радмило: Лингвистичка русистика у Југославији: развој, правци истраживања, актуелни задаци // Naučni skup Lingvistika i lingvističke aktivnosti u Jugoslaviji, (Sarajevo, 29-31. marta 1985) / glavni urednik Asim Peco. - Sarajevo: ANUBIH, 1987. - Str. 213-217.

Павловић-Шајтинац 2016: Павловић-Шајтинац, Маја: Лексикографија школских речника у српској и хрватској говорној и соииокултурној средини. Београд: Филолошки факултет, 2016. (докторска дисертација)

Пипер 1984: Пипер, Предраг: Библиографија југословенске лингвистичке русистике: (1945-1975). - Нови Сад: Матица српска, 1984. - 247 стр.; 25 cm. - (Библиографије / Матица српска. Рукописно одељење)

Пипер 1990: Пипер, Предраг: Библиографија југословенске лингвистичке русистике: (1976-1985). - Нови Сад: Матица српска, 1990.

Пипер 1996: Пипер, Предраг: Морфология русского языка в югославской русистике // Zbornik radova Instituta za strane jezike i književnosti (Novi Sad), 7 (1986), 159-171.

Пипер 1997: Пипер, Предраг: Конфронтациона проучавања српског и других словенских језика: славистички научноистраживачки пројекти // Славистика. - 1 (1997), 123-125.

Пипер 1998: Пипер, Предраг: Српска лингвистичка славистика деведесетих година XX века // Зборник Матице српске за славистику. - 54/55 (1998), 9-44. 
Пипер 2004: Пипер, Предраг: Сербские грамматики русского языка и проект сопоставительного синтаксиса русского и сербского языков // Международный симпозиум «Проекты по сопоставителному изучению русского и других языков» (Белград, 1-4, июня, 2004) / ред. Боголюб Станкович. - Београд: Славистичко друштво Србије, 2004. - Стр. 155-162.

Пипер 2010: Пипер, Предраг: О конфронтативним проучавањима руског и српског језика. // Контрастивна проучавања српског језика: правии и резултати / уредници Иван Клајн, Предраг Пипер. Београд: Српска академија наука и уметности, 2010. Стр. 241-261. (Српски језик у поређењу са другим језицима / САНУ, Одељење језика и књижевности ; књ. 1)

Пипер 2017: Пипер, Предраг: О српској лингвистичкој русистици друге половине XX века // К. Кончаревић (уред.), Универзитетска славистика: традииије, савремено стање, перспективе. Међународни научни зборник поводом 140 година Катедре за славистику Београдског универзитета $=$ Университетская славистика: диции, современное состояние, перспективы. Международный сборник научных статей, посвященный 140-летию Кафедры славистики Белградского университета, Београд: Филолошки факултет Београдског универзитета, 2017, 341-360.

Радојчић 2016: Радојчић, Ружица: Структурно-садржинске и функционалне карактеристике дидактичких граматика руског језика у инословенској (српској и хрватској) говорној средини. Београд: Филолошки факултет, 2016. (докторска дисертација)

\section{ВКЛАД ПРОФЕССОРА РАДМИЛО МАРОЕВИЧА \\ В СОПОСТАВИТЕЛЬНЫЕ И ТИПОЛОГИЧЕСКИЕ ИССЛЕДОВАНИЯ РУССКОГО И СЕРБСКОГО ЯЗЫКОВ}

\section{Резюме}

В предлагаемой работе рассматривается деятельность профессора, доктора филологических наук Радмило Мароевича в обосновании сербской лингвистической русистики, в первую очередь сопоставительного и типологического анализа русского и сербского языков, с учетом его важнейших результатов и исследовательских проблем. Подчеркивается, что Радмило Мароевич, основываясь на концепции акад. Радована Кошутича, внес существенный влад в такие дисциплины, как история, современное состояние и перспективы отечественной лингвистической русистики, в та- 
ких областях, как: информатика и библиографические исследования, лексикография, обоснование методологических основ сопоставительного и типологического анализа, сопоставительная фонетика, сопоставительный анализ грамматических систем, сопоставительное словообразование, лексикология, фразеология, воздействие русского языка на сербский, переводоведение, лингвометодика, лингвокультурология

Ключевые слова: лингвистическая русистика, сопоставительный и типологический анализ русского и сербского языков, история сербской славистики, Радмило Мароевич.

Ксенија Ј. Кончаревич 